\title{
Tadpole serum activity (Rana catesbeiana) in caspase-3 as a marker of the role of apoptosis and total cytotoxic $T$ Iymphocytes in albino rats' epithelial cells induced by neoplasia
}

\author{
M. T. E. Purnama ${ }^{1}$, I. H. Rahmaningtyas ${ }^{1}$, A. R. Pratama ${ }^{1}$, Z. Prastika ${ }^{1}$, A. M. Kartikasari ${ }^{2}$ and N. P. D. Cahyo ${ }^{2}$
}

1. Department of Veterinary Anatomy, Faculty of Veterinary Medicine, Universitas Airlangga, Mulyorejo Campus C Surabaya, East Java 60115, Indonesia; 2. Department of Veterinary Pathology, Faculty of Veterinary Medicine, Universitas Airlangga, Mulyorejo Campus C Surabaya, East Java 60115, Indonesia.

Corresponding author: M. T. E. Purnama, e-mail: thohawi@fkh.unair.ac.id

Co-authors: IHR: imas.hapsari.r-2014@fkh.unair.ac.id, ARP: arlian.reza.p-2014@fkh.unair.ac.id,

ZP: zeni.prastika-2014@fkh.unair.ac.id, AMK: anjani.marisa.kartikasari-2015@fkh.unair.ac.id, NPDC: nur.prabowo.dwi-2014@fkh.unair.ac.id

Received: 10-08-2018, Accepted: 26-11-2018, Published online: 10-01-2019

doi: 10.14202/vetworld.2019.63-67 How to cite this article: Purnama MTE, Rahmaningtyas IH, Pratama AR, Prastika Z, Kartikasari AM, Cahyo NPD (2019) Tadpole serum activity (Rana catesbeiana) in caspase-3 as a marker of the role of apoptosis and total cytotoxic T lymphocytes in Albino rats epithelial cells induced by neoplasia, Veterinary World, 12(1): 63-67.

\begin{abstract}
Aim: This study was conducted to examine the tadpole's serum activity (Rana catesbeiana) in caspase-3 as a marker of the role of apoptosis and total cytotoxic T lymphocyte (CTL) in albino rats' epithelial cells induced by neoplasia. Tadpole serumcontains thyroxine hormone that may cause the metamorphosis process and control cell proliferation.

Materials and Methods: Male rats were induced by 7,12-dimethylbenz ( $\alpha$ )anthracene (DMBA) $20 \mathrm{mg} / \mathrm{rats}$ twice every week over 5 weeks to stimulate skin neoplasia. Tadpole serum injected intracutaneously after neoplasia is known. The negative control group $(\mathrm{C}-$ ) was not exposed to DMBA and tadpole serum, while the positive control group $(\mathrm{C}+)$ was exposed to DMBA. Treatment groups (T1, T2, and T3) were exposed DMBA and tadpole serum 100\%, 75\%, and 25\%/rat/ day, respectively. Samples of skin organ were be made preparations immunohistochemistry interacted with caspase-3 and CTL antibody as the marker.
\end{abstract}

Results: Based on the result, immunohistochemistry from skin neoplasia and given therapy of tadpole serum show that Treatment 1 was the highest caspase-3 and CTL expression. The result of caspase- 3 expression in $\mathrm{C}-, \mathrm{C}+, \mathrm{T} 1, \mathrm{~T} 2$, and $\mathrm{T} 3$ was $0.00^{\mathrm{c}} \pm 0.000,0.70^{\mathrm{bc}} \pm 0.141,2.00^{\mathrm{a}} \pm 0.283,1.10^{\mathrm{b}} \pm 0.424$, and $1.15^{\mathrm{b}} \pm 0.495$, respectively. The result of CTL expression in $\mathrm{C}-, \mathrm{C}+, \mathrm{T} 1, \mathrm{~T} 2$, and T3 was $0.10^{\mathrm{d}} \pm 0.200,1.00^{\mathrm{c}} \pm 0.230,2.10^{\mathrm{a}} \pm 0.529,1.70^{\mathrm{ab}} \pm 0.258$, and $1.35^{\mathrm{bc}} \pm 0.443$, respectively.

Conclusion: It can be concluded from the study that tadpole serum (R. catesbeiana) 100\% concentration can increase caspase-3 and total CTL in albino rats' epithelial cells induced by neoplasia.

Keywords: caspase-3, cytotoxic T lymphocyte, Rana catesbeiana, serum, tadpoles.

\section{Introduction}

Cancer is one of the highest mortality diseases in the world. In 2012, there were 14 million new cases with 8 million mortality rate in the same year [1]. More than 232,000 cases of skin cancer were recorded, and among them, 55,000 cases resulted in the death [2]. Cancer cells are normal cells that undergo a change into malignant due to genetic abnormalities of these cells, so the ability of cell division is out of control. Malignant cells will trigger the growth of proto-oncogene cells so that normal cells will have potentially uncontrolled proliferation $[3,4]$. Mutation of genes in cancer increases cell proliferation and resistance to apoptosis mechanisms [5]. Some body molecular

\footnotetext{
Copyright: Purnama, et al. Open Access. This article is distributed under the terms of the Creative Commons Attribution 4.0 International License (http://creativecommons.org/licenses/ by/4.0/), which permits unrestricted use, distribution, and reproduction in any medium, provided you give appropriate credit to the original author(s) and the source, provide a link to the Creative Commons license, and indicate if changes were made. The Creative Commons Public Domain Dedication waiver (http:// creativecommons.org/publicdomain/zero/1.0/) applies to the data made available in this article, unless otherwise stated.
}

systems are used to induce apoptosis pathways to inhibit tumor cell growth [6].

Thyroxine hormone leads an important role in different organs and tissues [7]. Thyroxine hormone increases gene expression associated with proliferation, cell differentiation, and development of body shape in tadpoles [8,9]. Thyroxine hormone can induce apoptosis and minimize myogenesis of tadpole in the process of metamorphosis [10]. Apoptosis is programmed cell death. Apoptosis is an important mechanism in embryonic development, organogenesis, and metamorphosis [11]. In the frog metamorphosis, the tail tissue undergoes apoptosis due to an increase in thyroxine hormone [12].

The aim of this study was to examine the potential serum of tadpoles (Rana catesbeiana) in caspase-3 as a marker of the role of apoptosis and total cytotoxic T lymphocyte (CTL) in albino rats' epithelial cells induced by neoplasia. Tadpole serum containing thyroxine hormone is expected to induce the apoptosis process in skin epithelial cells, thus becoming a solution to inhibit the development of proto-oncogene cells. 


\section{Materials and Methods}

\section{Ethical approval}

This study was approved by the Ethical Committee with Ethical Clearance No: 686-KE Animal Care and Use Committee, Faculty of Veterinary Medicine, Universitas Airlangga.

\section{Procedures for 7,12-dimethylbenz ( $\alpha$ )anthracene (DMBA) administration}

This study was used male rat Sprague Dawley strain of 20 rats weighing $200 \mathrm{~g}$. Adaptation in animals is done for 1 week with a cluster-type enclosure. Healthy condition was determined by their active movement. Dosage induction DMBA (SigmaAldrich ${ }^{\circledR}$ with CAS number 57-97-6) as a reagent to induce cancer cells according to research reported as much $20 \mathrm{mg} /$ rats twice every week for 5 weeks [13]. To present skin cancer cells in this study, injected DMBA according to induction dose intracutaneously using a tuberculin syringe. Before induction, DMBA powder was dissolved in corn oil to facilitate the induction process by comparison in $1 \mathrm{ml}$ of corn oil containing $20 \mathrm{mg}$ doses of DMBA.

\section{Isolation of tadpole serum}

Tadpole blood 45-46 days old was collected through intracardial using a tuberculin syringe [14]. To increase the serum volume, the blood was then centrifuged for $15 \mathrm{~min}$ at a speed of $1000 \mathrm{rpm}$. Tadpole serum moved on a tube, covered with aluminum foil, and placed into the refrigerator with the temperature around $-15^{\circ} \mathrm{C}-30^{\circ} \mathrm{C}$.

\section{Procedures for tadpole serum injection}

This study was an experimental laboratory using a completely randomized design for 20 rats. They were divided into five treatments in which each treatment was subjected to four replications as follows: Negative control group $(\mathrm{C}-)$ was not exposed to DMBA and tadpole serum; positive control group $(\mathrm{C}+)$ was exposed to DMBA; treatment groups (T1, T2, and T3) were exposed DMBA and tadpole serum 100\%, 75\%, and $25 \% / \mathrm{rat} /$ day, respectively. Tadpole serum was injected intracutaneously in DMBA injected site. Natural killer $(\mathrm{NK})$ cell stimulation was performed by interferon gamma (INF- $\gamma$ ) with thyroxine hormone used a minimal dose of $0.01-0.1 \mathrm{mg} / \mathrm{ml}$ [15]. Thyroxine hormone in tadpole serum is $0.94 \mu \mathrm{g} / \mathrm{dl}$ [16]. In this study, we used a therapeutic dose of $0.01 \mathrm{mg} / \mathrm{ml}$ with detailed treatment; Treatment 1 used serum dose of $1.06 \mathrm{ml} / \mathrm{rat} / \mathrm{day}$, Treatment 2 used serum dose of $0.71 \mathrm{ml} / \mathrm{rat} / \mathrm{day}$ and buffer solution $0.35 \mathrm{ml} / \mathrm{rat} /$ day, and Treatment 3 used serum dose of $0.27 \mathrm{ml} / \mathrm{rat} /$ day and buffer solution $0.79 \mathrm{ml} / \mathrm{rat} /$ day.

\section{Animal surgical procedures}

After the dislocation of the ossa cervical atlanto-occipitale, surgery has been done by shaving the hair and skin incision. The skins were separated from the other connective tissue and then stored in formaldehyde $15 \%$ for making preparations for immunohistochemistry staining.

\section{Procedures for immunohistochemistry staining}

The skins were stored in formaldehyde 15\% for $48 \mathrm{~h}$. Furthermore, alcohol was used as a dehydration agent with concentration of $70 \%, 80 \%$, and $96 \%$. Xylol was used for clearing process and continued making paraffin block with $60^{\circ} \mathrm{C}$ of the temperature. The skin tissue that has received paraffin blocks then sliced using a microtome machine and then transferred into a water bath before being placed on a glass object. Immunohistochemistry staining was used primary antibody caspase-3 anti-rat (PE Active Caspase-3 Apoptosis Kit BD Pharmingen ${ }^{\mathrm{TM}}$ with CAS number 550914) and CTL (ATCC ${ }^{\circledR}$ PCS$800-017^{\mathrm{TM}}$ ) for $1 \mathrm{~h}$ in $27^{\circ} \mathrm{C}$. The dilution was given $10 \mu \mathrm{l}$ for caspase- 3 and $0.1 \mathrm{ml}$ for CTL test. Caspase- 3 was executor primary antibody [17]. Then, the specimen washed in phosphate buffered saline (PBS) with a $\mathrm{pH}$ of 7.4 for 3 times every $5 \mathrm{~min}$. The next preparations were added streptavidin-horseradish peroxidase for $60 \mathrm{~min}$ in $27^{\circ} \mathrm{C}$ and washed in PBS with $\mathrm{pH}$ 7.4. Then, the specimens were added chromogen 3,3-Diaminobenzidine tetrahydrochloride for $20 \mathrm{~min}$ and washed with aquadest for $5 \mathrm{~min}$.

\section{Observations of skin scoring with immunohisto- chemistry staining}

The observations were focused on the caspase- 3 and CTL expression of skin epithelial cell. The intensity of the visual field brownish $0 \%$ with a score of 0 means normal, intensity of $0-25 \%$ of the visual field with a score of 1 means low, intensity $25-50 \%$ of the visual field with a score of 2 means medium, and the intensity of the visual field $>50 \%$ with a score of 3 means high [18]. Scoring was done as many as 10 of the visual field in each replication with a magnification of 1000 times, and the observations were made with a microscope Nikon ${ }^{\circledR}$ E-200 LED Trinocular Microscope.

\section{Statistical analysis}

The mean score of the observations was tested by Kolmogorov-Smirnov for the normality test. If the data normal distribution, then continued with one-way ANOVA test and if a significant difference $(\mathrm{p}<0.05)$ was found, the analysis was followed with Duncan's test. All the processes of analyses were used SPSS v21 software (IBM, USA).

\section{Results}

The results of the observation showed that the brownish color was qualitative with the caspase-3 antibody primer and CTL expression. Table- 1 shows the mean and SD with a significant difference between treatments $(\mathrm{p}<0.05)$. Treatment 1 was an effective given $100 \%$ tadpole serum as the highest score caspase- 3 and CTL expression followed by Treatment 2 of $75 \%$ tadpole serum and Treatment 3 of $25 \%$ tadpole serum. Caspase-3 (Figure-1) and CTL (Figure-2) show the different color intensity of skin epithelial cell between each treatment. This means that tadpole 
Table-1: Mean and SD caspase-3 and CTL expression.

\begin{tabular}{llc}
\hline Treatments & \multicolumn{2}{c}{ Mean \pm SD } \\
\cline { 2 - 3 } & Caspase-3 & CTL \\
\hline C- & $0.00^{\mathrm{c}} \pm 0.000$ & $0.10^{\mathrm{d}} \pm 0.200$ \\
C+ & $0.70^{\mathrm{bc}} \pm 0.141$ & $1.00^{\mathrm{c}} \pm 0.230$ \\
T1 & $2.00^{\mathrm{a}} \pm 0.283$ & $2.10^{\mathrm{a}} \pm 0.529$ \\
T2 & $1.10^{\mathrm{b}} \pm 0.424$ & $1.70^{\mathrm{ab}} \pm 0.258$ \\
T3 & $1.15^{\mathrm{b}} \pm 0.495$ & $1.35^{\mathrm{bc}} \pm 0.443$
\end{tabular}

Different superscripts in the same column indicate significant differences among treatments $(p<0.05)$, $\mathrm{CTL}=$ Cytotoxic $\mathrm{T}$ lymphocyte, $\mathrm{SD}=$ Standard deviation

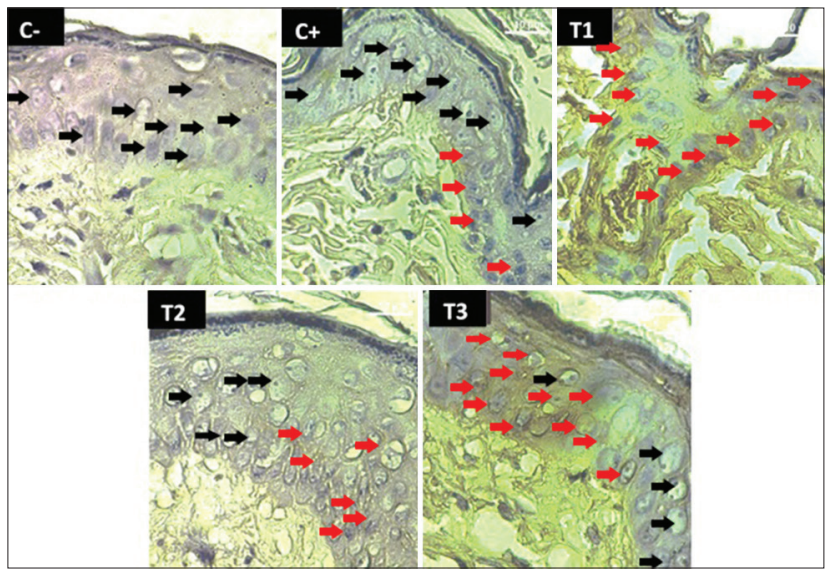

Figure-1: Caspase- 3 expression in the treatments of $\mathrm{C}-, \mathrm{C}+, \mathrm{T} 1, \mathrm{~T} 2$, and T3. $(\rightarrow)$ The black arrow shows the normal skin epithelial cell, $(\rightarrow)$ the red arrow shows the caspase- 3 expression of skin epithelial cell.

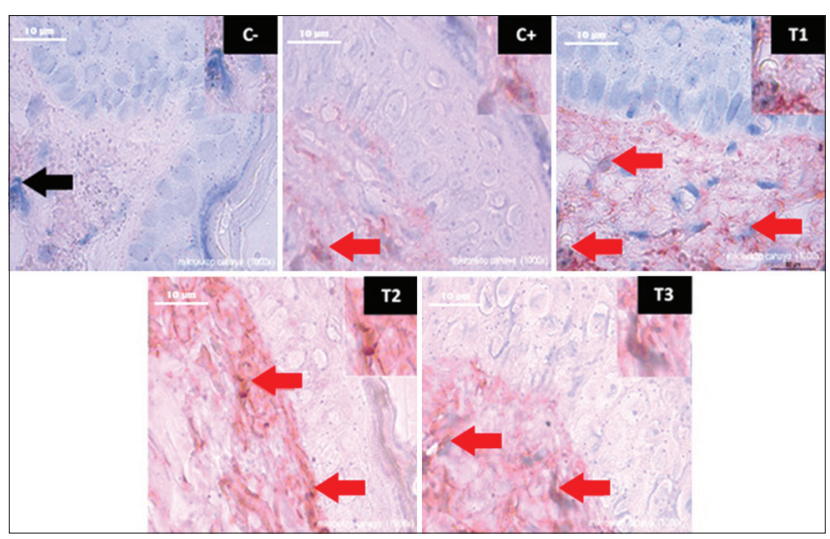

Figure-2: Cytotoxic $\mathrm{T}$ lymphocyte (CTL) expression in the treatments of $\mathrm{C}-, \mathrm{C}+, \mathrm{T} 1, \mathrm{~T} 2$, and T3. $(\rightarrow)$ The black arrow shows the normal T lymphocyte, $(\rightarrow)$ the red arrow shows CTL expression on skin epithelial cell.

serum $100 \%$ can induce apoptosis process on skin epithelial cell albino rats induced by neoplasia.

\section{Discussion}

Based on Table-1, Treatment 1 shown $2.00^{\circ} \pm 0.283$ as the highest value of apoptosis occurrence because this treatment was given a $100 \%$ dose of tadpole serum. Apoptosis occurrence is indicated by an assessment of the caspase- 3 . If compared with positive control group $(\mathrm{C}+)$ only induced by $\mathrm{DMBA}$ without treatment tadpole serum, the apoptosis score was only $0.70^{\mathrm{bc}} \pm 0.141$ for caspase- 3 . Treatments 2 and 3 have a score of $1.10^{\mathrm{b}} \pm 0.424$ and $1.15^{\mathrm{b}} \pm 0.495$ smaller than Treatment 1.

Based on Table-1, results of the mean Treatment 1 indicate the mean of CTL $2.10^{\mathrm{a}} \pm 0.529$, in which Treatment 2 is $1.70^{\mathrm{ab}} \pm 0.258$, and Treatment 3 is $1.35^{\mathrm{bc}} \pm 0.443$. The significant difference occurred between Treatment 1 and Treatment 3 but no significant between Treatment 1 with Treatment 2 and Treatment 2 with Treatment 3 .

Tadpole on stage 21-23 days old contains thyroxine hormone in blood serum. The concentration of thyroxine hormone contains $0.94 \mu \mathrm{g} / \mathrm{dl}$ [16]. The thyroxine hormone was measured by radioimmunoassay double antibodies in blood serum and pericardial fluid bullfrog tadpoles. Tadpole on stage 5-18 days old also has the thyroxine hormone concentrations $<0.20 \mathrm{mg} / \mathrm{dl}$ and began to be detected in its initial of metamorphosis stage 19-20 days old [19].

The thyroxine hormone leads a role in tadpole apoptosis, so tail regression occurs. [19]. This is also supported by the role of thyroxine hormone in the metamorphosis of tadpole [3]. Thyroxine hormone has a function in apoptosis of the frog, so the regression occurs in the tail [20-22]. This invention applied in this research so that serum which is contained with thyroxine hormone can inhibit proto-oncogene cell proliferation. Thyroxine hormone can increase humoral and cellular immune response. Humoral immune response increases the number of NK cells while the cellular immune response increases the number of CTL [23]. Both cells worked specifically to inhibit proto-oncogene cell proliferation and killed cancer cells so that the apoptosis process happened [24-27].

Apoptosis of skin cancer cells is shown in caspase-3 (Figure-1) and CTL (Figure-2) with brownish color on skin epithelial cells. CTLs are a type of white blood cell that can prevent intracellular pathogens and become a marker of the process of the phagocytosis of cancer cells. Apoptosis happened because CTL and NK cells kill cancer cells $[28,29]$. Apoptosis can be through extrinsic pathways in death receptor and intrinsic pathways or mitochondrial pathways. Through extrinsic pathways, there is a relationship between ligand and death receptor so that can activate sequential caspase- 8 as the initiator of the apoptosis process [30-33]. Tumor necrosis factor (TNF) which consists of cytoplasmic domains is called the death domain. Death domains will transmit apoptotic signals through TNF receptor Type-1 and connect to a Fas protein (CD95) that will bind to Fas ligand. Cytoplasmic Death Domain forms the binding site as a Fas-associated death domain (FADD) protein adapter. The FADD protein will bind to pro-caspase 8 to activate caspase- $8[30,34]$. Caspase- 8 will initiate the release of caspase- 3 which acts as the executor of the apoptosis process [17]

Increasing the number of CTL occurs due to the influence of tadpole serum ( $R$. catesbeiana) containing the hormone thyroxine. Dendritic cells can help the 
thyroid hormone as a cancer vaccine to stimulate CTL as immunotherapy [7]. Other studies using L-thyroxine $\left(\mathrm{T}_{4}\right)$ and 3,3,5-triido-L-thyronine $\left(\mathrm{T}_{3}\right)$ could stimulate the proliferation of $\mathrm{T}$ lymphocytes [23]. Thyroxine hormone that used low doses could increase the stimulatory effect of IFN- $\gamma$ [15]. Giving triiodothyronine was able to stimulate an antitumor CTL response [12].

The thyroid gland regulates the immune system indirectly by released hormones and cytokines. The cytokines include IFN- $\gamma$ (15). 3,3,5-Triido-Lthyronine $\left(\mathrm{T}_{3}\right)$ and L-thyroxine $\left(\mathrm{T}_{4}\right)$ could modulate specific immune response, issued cell-mediated immunity, NK cell activity, as a result of IFN antiviral response and the proliferation of T lymphocytes [34].

\section{Conclusion}

Tadpole serum (R. catesbeiana) 100\% concentration can increase caspase- 3 and total CTL in albino rats' epithelial cells induced by neoplasia. Tadpole serum can be used as a cancer therapy with further research.

\section{Authors' Contributions}

MTEP and IHR supervised the experiment. ARP and NPDC helped in immunohistochemistry method. IHR, AMK, and ZP conducted the study. MTEP helped in the statistical analysis of the data. MTEP, IHR, and ARP helped in the preparation of tables and figure, revised, and submitted the manuscript. All authors read and approved the final manuscript.

\section{Acknowledgments}

The authors acknowledge the Directorate General of Higher Education (DIKTI), the Research, Technology and Higher Education, the Republic of Indonesia with grant number 532/UN3.1.16/LT/2017 for providing fund support to carry out this study.

\section{Competing Interests} interests.

The authors declare that they have no competing

\section{Publisher's Note}

Veterinary World remains neutral with regard to jurisdictional claims in published map and institutional affiliation.

\section{References}

1. Ferlay, J., Soerjomataram, I., Ervik, M., Dikshit, R., Eser, S., Mathers, C., Rebelo, M., Parkin, D. M., Forman, D. and Bray, F. (2013) GLOBOCAN 2012 v1. 0, Cancer Incidence and Mortality Worldwide: IARC Cancer Base No. 11. International Agency for Research on Cancer, Lyon, France. p19.

2. Gulland, A. (2014) Global cancer prevalence is growing at" alarming pace," says WHO. Br. Med. J., 348(7944): g1338.

3. Hanahan, D. and Weinberg, R.A. (2000) The hallmarks of cancer. Cell, 100(1): 57-70.

4. Nurhayati, S. and Lusiyanti, Y. (2014) Apoptosis dan respon biologik sel sebagai faktor prognosa radioterapi kanker. Bul. Alara, 7(3): 57-66.

5. Wang, R.A., Li, Q.L., Li, Z.S., Zheng, P.J., Zhang, H.Z., Huang, X.F., Chi, S.M., Yang, A.G. and Cui, R. (2013) Apoptosis drives cancer cells to proliferate and metastasize.
J. Cell. Mol. Med., 17(1): 205-211.

6. Bai, L. and Wang, S. (2014) Targeting apoptosis pathways for new cancer therapeutics. Annu. Rev. Med., 65(1): 139-155.

7. Du, C.C., Li, X.Y., Wang, H.X., Liang, K., Wang, H.Y. and Zhang, Y. (2017) Identification of thyroid hormone receptors $\alpha$ and $\beta$ genes and their expression profiles during metamorphosis in Rana chensinensis. Turk. J. Zool., 41(3): 454-463.

8. Thompson, C.K. and Cline, H.T. (2016) Thyroid hormone acts locally to increase neurogenesis, neuronal differentiation, and dendritic arbor elaboration in the tadpole visual system. J. Neurosci., 36(40): 10356-10375.

9. Thompson, C.K. (2013) Thyroid hormone induces major changes in body plan development in pre-metamorphic Xenopus laevis tadpoles. Mol. Reprod. Dev., 80(10): 219-229.

10. Tamura, K., Takayama, S., Ishii, T., Mawaribuchi, S., Takamatsu, N. and Ito, M. (2015) Apoptosis and differentiation of Xenopus tail-derived myoblasts by thyroid hormone. J. Mol. Endocrinol., 54(3):185-192.

11. Exbrayat, J.M., Moudilou, E.N., Abrouk, L. and Brun, C. (2012) Apoptosis in amphibian development. Adv. Biosci. Biotechnol., 3(6): 669.

12. Alberts, B., Bray, D., Hopkin, K., Johnson, A., Lewis, J., Raff, M., Roberts, K. and Walter, P. (2013) Essential Cell Biology. Garland Science, New York. p101-118.

13. Cabeças, J.R., Costa, E., Alves, G., Jesus, P. and Cabrita, A. (2014) Oral cavity morphometric evaluation in 7,12-dimethylantracene administration (1139.11). FASEB J., 28(1): 1139.

14. Das, M. and Mahapatra, P. K. (2014) Hematology of wild caught Dubois's tree frog Polypedates teraiensis, Dubois, 1986 (Anura: Rhacophoridae). Sci. World J., 2014(1): 7.

15. Provinciali, M. and Fabris, N. (1990) Modulation of lymphoid cell sensitivity to interferon by thyroid hormones. J. Endocrinol. Invest., 13(2): 187-191.

16. Mondou, P.M. and Kaltenbach, J.C. (1979) Thyroxine concentrations in blood serum and pericardial fluid of metamorphosing tadpoles and of adult frogs. Gen. Comp. Endocrinol., 39(3): 343-349.

17. Kumar, V., Abbas, A.K., Fausto, N. and Aster, J.C. (2014) Robbins and Cotran Pathologic Basis of Disease, Professional Edition e-book. Elsevier Health Sciences, Philadelphia p98-128.

18. Sinuhaji, I., Siregar, B. and Lisnawati, L. (2013) P16INK4A expression in cervical carcinoma young age. J. Indones. Med., 63(1): 165-71.

19. Gudernatsch, J.F. (1914) Feeding experiments on tadpoles. II. A further contribution to the knowledge of organs with internal secretion. Am. J. Anat., 15(4): 431-480.

20. Nakajima, K., Fujimoto, K. and Yaoita, Y. (2005) Programmed cell death during amphibian metamorphosis. Semin. Cell Dev. Biol., 16(2): 271-280.

21. Kerr, J.F.R., Harmon, B. and Searle, J. (1974) An electron microscope study of cell deletion in the anuran tadpole tail during spontaneous metamorphosis with special reference to apoptosis of striated muscle fibres. J. Cell Sci., 14(3): 571-585.

22. Gilbert, L.I., Tata, J.R. and Atkinson, B.G. (1996). Metamorphosis: Postembryonic Reprogramming of Gene Expression in Amphibian and Insect Cells. Academic Press, USA. p145.

23. Hodkinson, C.F., Simpson, E.E., Beattie, J.H., O'Connor, J.M., Campbell, D.J., Strain, J.J. and Wallace, J.M. (2009) Preliminary evidence of immune function modulation by thyroid hormones in healthy men and women aged 55-70 years. J. Endocrinol., 202(1): 55-63.

24. Bie, G.H. and Reijnhart, S. (2006) Immunology: Self and Non-self from a Phenomenological Point of View. Louis Bolk Instituut, Driebergen. p72.

25. von Bubnoff, D., Andrès, E., Hentges, F., Bieber, T., Michel, T. and Zimmer, J. (2010). Natural killer cells in atopic and autoimmune diseases of the skin. J. Allergy Clin. Immunol., 125(1): 60-68. 
26. Lowdell, M.W. (2012). Natural Killer T cells-balancing the regulation of tumor immunity. Br. J. Cancer, 107(10): 1795.

27. Don, M.M., Ablett, G., Bishop, C.J., Bundesen, P.G., Donald, K.J., Searle, J. and Kerr, J.F.R. (1977) Death of cells by apoptosis following attachment of specifically allergized lymphocytes in vitro. Aust. J. Exp. Biol. Med. Sci., 55(4): 407-417.

28. Hayden, M., Schroter, S. and Minev, B.R. (2006) Analyzing $\mathrm{T}$ cell responses: How to analyze cellular immune responses against tumor-associated antigens. Apoptosis, 11(9): 1657-1658.

29. Muppidi, J.R., Tschopp, J. and Siegel, R.M. (2004) Life and death decisions: Secondary complexes and lipid rafts in TNF receptor family signal transduction. Immunity., 21(4): 461-465.

30. Krammer, P.H., Arnold, R. and Lavrik, I.N. (2007) Life and death in peripheral T cells. Natl. Rev. Immunol., 7(7): 532.

31. Johnstone, R.W., Frew, A.J. and Smyth, M.J. (2008) The TRAIL apoptotic pathway in cancer onset, progression and therapy. Natl. Rev. Cancer, 8(10): 782.

32. Vilar, M. (2017) Structural characterization of the p75 neurotrophin receptor: A stranger in the TNFR superfamily. Vitam. Horm., 104(10): 57-87.

33. Purnama, M.T.E. and Samik, A. (2014) Potential mycotoxin binders on histopathology of the mammary gland experiencing neoplasia in pregnant mice (Mus musculus) with exposed zearalenone. Vet. Med., 7(1): 73-80.

34. Zachary, J.F. and McGavin, M.D. (2013) Pathologic Basis of Veterinary Disease-E-Book. Elsevier Health Sciences, Philadelphia p38-81.

$* * * * * * * *$ 